\title{
Selection of artificial hosts for oviposition by wild Anastrepha obliqua (Macquart) (Diptera, Tephritidae): influence of adult food and effect of experience
}

\author{
Thamara A. B. S. Leal ${ }^{1} \&$ Fernando S. Zucoloto ${ }^{2}$
}

\author{
1,2Departamento de Biologia, FFCLRP, Universidade de São Paulo, Avenida Bandeirantes, 3900, 14040-901 Ribeirão Preto-SP, Brazil \\ ${ }^{1}$ thaleal@usp.br; ${ }^{2}$ zucoloto@ ffclrp.usp.br
}

\begin{abstract}
Selection of artificial hosts for oviposition by wild Anastrepha obliqua (Macquart) (Diptera, Tephritidae): influence of adult food and effect of experience. Several factors influence the selection of oviposition substrates by insects. The aim of the present work was to find answers to the following questions related to the oviposition behavior of Anastrepha obliqua. Can carbohydrates (glucose or sucrose) present in the adult diet have influence on the female preference for an oviposition substrate with similar composition? Can the previous experience with a host containing one of mentioned carbohydrates interfere in further selection of oviposition substrates? The results showed that the kind of carbohydrate present in the adult diet did not affect the female preference for an artificial oviposition substrate, neither when it was presented by itself nor in combination with brewer's yeast. The effect of experience in the oviposition behavior was observed when there was a previous contact with artificial oviposition substrates containing yeast and sucrose. The data are discussed in terms of the behavioral plasticity presented by this species in relation to feeding and oviposition behaviors.
\end{abstract}

KEYWORDS. Carbohydrate; feeding behavior; fruit flies; induced preference; oviposition behavior.

\begin{abstract}
RESUMO. Seleção de hospedeiros artificiais para oviposição por Anastrepha obliqua (Macquart) (Diptera, Tephritidae) selvagem: influência do alimento do adulto e efeito da experiência. Vários fatores podem atuar durante a seleção de substratos para oviposição por insetos. O presente estudo teve por objetivo responder às seguintes questões relacionadas ao comportamento de oviposição de Anastrepha obliqua. O carboidrato presente na dieta do adulto (glicose ou sacarose) pode influenciar a preferência da fêmea por um substrato para oviposição com composição semelhante? A experiência prévia com um hospedeiro que possui um dos dois carboidratos citados pode interferir em escolhas futuras entre substratos para oviposição? Os resultados indicaram que o tipo de carboidrato presente na dieta do adulto não exerceu influência sobre a preferência das fêmeas por um substrato artificial para oviposição, tanto quando em combinação com lêvedo de cerveja ou quando sozinho. O efeito da experiência no comportamento de oviposição foi notado quando o contato prévio foi com substratos artificiais para oviposição contendo lêvedo e sacarose. Os resultados são discutidos com base na plasticidade comportamental apresentada pela espécie com relação ao comportamento alimentar e de oviposição.
\end{abstract}

PALAVRAS-CHAVE. Carboidrato; comportamento alimentar; comportamento de oviposição; indução comportamental; moscas-das-frutas.

The oviposition preference/offspring performance hypothesis predicts that oviposition preference may be related to an appropriate host for the development of offspring. Thus, an adult female maximizes its fitness by ovipositing in hosts that optimize the larvae performance (Thompson 1988; Scheirs 2002; Nufio \& Papaj 2004).

However, several factors influence the selection for oviposition host by insects and contribute to the lack of a correspondence between female preference and larvae performance (Nufio \& Papaj 2004). Among these factors, there are: alelochemicals, nutritional composition, plant morphology, presence of natural enemies, availability of appropriate host, food resource used by the adult insect, and its previous experience (Dethier 1982; Prokopy \& Roitberg 1984; Thompson 1988; Thompson \& Pellmyr 1991; Scheirs 2002; FontellasBrandalha \& Zucoloto 2004).

In some cases, the females lay eggs in hosts that serve as food to the adult and confer them a better performance, being sub-optimals to the larva performance. In experiments with oligophagous species Chromatomyia nigra (Meigen, 1830) (Diptera), females laid eggs where they fed, and such host conferred better performance to the adult than to the larvae (Scheirs et al. 2000).

The previous experience plays an important role in the host plant's recognition and preference processes (Dethier 1982). The effect of experience comes from a large range of mechanisms, which may include habituation, increase in the ability of processing toxicant substances, sensitization, induction and associative learning (Bernays 1995; Bernays \& Weiss 1996).

Studies with different insect species showed that the previous oviposition experience on a given host may also affect future host choices for oviposition (Papaj \& Prokopy 1989; Cunningham et al. 1998; Joaquim-Bravo et al. 2001). The term induction (or induced preference) is used in selection preference tests in which phytophagous insects choose a plant 
which they have already experienced instead of another they have not (Bernays 1995).

Anastrepha obliqua fruit flies (Macquart, 1835) are polyphagous, multivoltine and present an oviposition behavior that includes several stages (Aluja et al. 2000) which can be affected by a series of environmental and physiological factors (Dukas et al. 2001).

The first aim of the present study was to investigate whether the nutritional composition of adult diet has effect on the preference for an oviposition substrate. The nutritional component evaluated was carbohydrate. The second aim was to verify the existence of induced preference in the selection of an artificial oviposition site following a previous contact with a given substrate, during the first days of the oviposition period.

\section{MATERIALAND METHODS}

Wild A. obliqua adults from "cajá-manga" - Spondias venulosa (Engler, 1876) - and "cajá-mirim" - S. lutea (Linnaeus, 1762) - fruits were used. These fruits were collected at the "Fazenda Experimental do Instituto Agronômico de Campinas" and at the "Museu Municipal de Ribeirão Preto", both located in Ribeirão Preto, SP, Brazil. After collected, the fruits were kept in plastic trays $(60 \times 40 \times 10 \mathrm{~cm})$ with clean sand, until the insects reach the pupae stage. Then, the pupae were transferred to acrylic boxes $(11 \times 11 \times 3.5 \mathrm{~cm})$ containing sterilized sand. After the emergence, the adults were placed in groups of $16\left(10 \%, 60^{\prime}\right)$ individuals $/$ box $(11 \times 11 \times 7 \mathrm{~cm})(1 \mathrm{box}=1$ replicate). There were a total of 6 experimental groups, with 10 replicates each.

The experiments were performed at temperature $\left(27 \pm 1^{\circ} \mathrm{C}\right)$ and humidity $(70 \pm 5 \%)$ controlled, under a 12:12 light/dark cycle, through fluorescent lights (400 lux).

Water and solid diet were offered ad libitum to the flies. The diets were composed by distilled water $100 \mathrm{ml}$; agar $3.0 \mathrm{~g}$ (Vetec, Rio de Janeiro, Brazil); brewer's yeast 6.5g (Oficina de Ervas, Ribeirão Preto, Brazil); carbohydrate 11.0g and Nipagin $1.5 \mathrm{ml}$ (Merck, Darmstadt, Germany) in 20\% alcoholic solution. Two different carbohydrates were used: glucose (Merck, Darmstadt, Germany) and sucrose (Synth, Diadema, Brazil).

The artificial host for oviposition had an oval shape and $6 \mathrm{ml}$ volume. They were wrapped with Parafilm (American Can Company, Detroit, USA), in order to provide the female resistance for the ovipositor, just as the host fruits skin. Four different artificial substrates were used: YG substrate (yeast and glucose) composed by distilled water $100 \mathrm{ml}$, agar $2.5 \mathrm{~g}$, brewer's yeast $6.5 \mathrm{~g}$, glucose $11.0 \mathrm{~g}$; YS substrate (yeast and sucrose) composed by distilled water $100 \mathrm{ml}$, agar $2.5 \mathrm{~g}$, brewer's yeast $6.5 \mathrm{~g}$, sucrose $11.0 \mathrm{~g}$; G substrate (glucose) composed by distilled water $100 \mathrm{ml}$, agar $2.5 \mathrm{~g}$, glucose $11.0 \mathrm{~g}$; S substrate (sucrose) composed by distilled water $100 \mathrm{ml}$, agar $2.5 \mathrm{~g}$, sucrose 11.0g.

In this work, oviposition preference was evaluated by the number of eggs laid daily on each artificial oviposition substrate.
In Experiment 1, 4 groups were formed with combinations of two artificial substrates for oviposition: Group 1: YG x YS substrates available for females fed on yeast and glucose diet; Group 2: YG x YS substrates available for females fed on yeast and sucrose diet; Group 3: G x S substrates available for females fed on yeast and glucose diet; Group 4: G x S substrates available for females fed on yeast and sucrose diet.

Similarly to previous studies, the artificial hosts for oviposition were placed in the experimental boxes from day 18 after the adult emergence, because the females begin to oviposit near this age (Fontellas-Brandalha \& Zucoloto 2004). Samples were collected during the first 6 days in which females laid eggs. The substrates were replaced every day.

In Experiment 2, two experimental groups were formed (Groups 5 and 6), both composed by flies fed on yeast and sucrose diet.

The insects of the Groups 5 and 6 were placed with YG and YS substrates, respectively, from day $18^{\text {th }}$ of adult life. When eggs were detected on substrates of each experimental box, the female remained with the same kind of substrate for more 2 days, totalizing 3 days for oviposition on the YG (Group 5) or YS (Group 6) sites. On the three following days, flies of both groups had to choose between the YG or YS oviposition substrates. All substrates used were replaced every day.

Data Analysis. The Kolmogorov-Smirnov test was used to verify normality. As only some groups presented a normal distribution of the data, the Wilcoxon non-parametric test was used to verify the preference for oviposition substrates within the same group. These tests were conducted using the SigmaStat program for Windows Version 2.03 - Jandel Corporation. The level of significance was at $5 \%$.

\section{RESULTS}

In Experiment 1, the number of eggs laid by flies fed on yeast and glucose diet (Group 1) on YG and YS substrates was not significantly different in 5 out of 6 days of selection. Similar results were found for the flies fed on yeast and sucrose (Group 2) on each of the 6 oviposition days (Table I).

When the substrates did not contain yeast, the number of eggs which flies fed on yeast and glucose (Group 3) or yeast and sucrose (Group 4) laid on G substrate was not significantly different from the ones laid on the S substrate, in 4 out of the 6 test days. On the remaining days, in both groups, the number of eggs laid was greater on S substrates (Table II).

In Experiment 2, the number of eggs laid by females which had an experience of oviposition on YG substrate (Group 5) was not significantly different from YG and YS substrates, in any of the 3 days of selection. Flies that had previous contact with YS substrate (Group 6) showed no difference in relation to the number of eggs laid on YG and YS substrates on the first day of test. However, on the second and third days, the number of eggs laid on the YS substrates was greater (Fig. 1). 


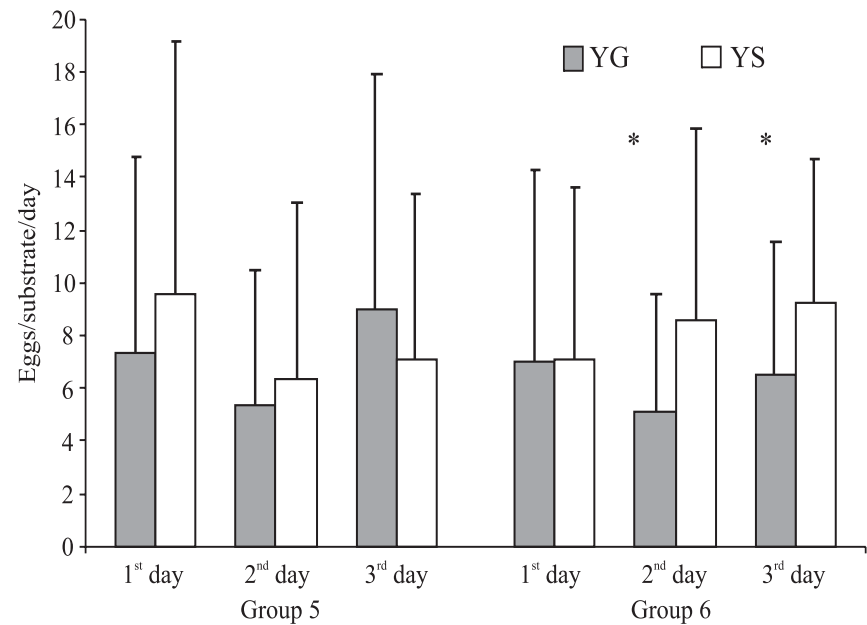

Fig. 1. Mean number of eggs laid on each of the three selection days on YG (yeast and glucose) and YS (yeast and sucrose) substrates, by $A$. obliqua flies which had a 3-day previous contact with YG (Group 5) or YS (Group 6). * indicates significant difference, according to the Wilcoxon test, $\mathrm{p}<0.05 .^{\mathrm{T}}=$ standard deviation.

\section{DISCUSSION}

In the present work, the effect of the adult food on the selection of a host for oviposition would have been verified whether the flies had selected the substrate containing a carbohydrate similar to the diet they were receiving. Such effect was not found in the Groups 1 and 2, in which brewer's yeast was present in the artificial substrate composition to oviposition.

Fontellas \& Zucoloto (1999) showed that A. obliqua adult females fed on diets combining yeast and glucose or yeast and sucrose presented no difference in relation to daily ingestion/female, eggs production, diet efficiency and survival. Therefore, the similar nutritional value of the YG and YS substrates for A. obliqua may explain the lack of effect of the adult food on the oviposition site selection for Groups 1 and 2 in the present work.

In insects, contact chemoreceptors (or gustatory receptors) are involved in the regulation of oviposition, and sometimes in the selection of a sexual partner, as well as, in feeding habits. They are usually present in the antennae, tarsi, mouthparts (Chapman 2003). The female ovipositor of tephritid has mechano, hygro and gustatory receptors. Stimuli proceeding from gustatory receptor present in the tarsi and labellum also affect oviposition (Rice 1989). In Rhagoletis pomonella (Walsh, 1864), certain tarsal gustatory sensilla showed great sensitivity to the oviposition deterring pheromone (Crnjar \& Prokopy 1982).

Electrophysiological studies with Ceratitis capitata (Wiedemann, 1824) adults showed a high frequency of labellar sensilla responses elicited by sucrose, glucose and fructose solutions, evidencing that a cell responds to these sugars (Gothilf et al. 1971). The hypothesis of a common receptor for sucrose and glucose was raised in studies with $C$. capitata larvae because they did not exhibit a preference for diets containing glucose or sucrose as a result of rearing diet, privation or previous experience (Canato \& Zucoloto 1998).

In this context, a common receptor for sucrose and glucose could explain the results found in the Groups 1 and 2 with $A$. obliqua. However, the results from the Groups 3 and 4 showed that $A$. obliqua females are able to distinguish between glucose and sucrose. Selection studies with Drosophila larvae suggest that sucrose and fructose bind to a different site from glucose, because a low concentration of sucrose or fructose was detected in the presence of a high concentration of glucose. On the other hand, the co-existence of two sites on the same cell was not discarded (Miyakawa 1982).

Gustatory sensilla usually have phagostimulatory and deterrent neurons. When a sensillum encounters a mixture of compounds, the neuronal responses not necessarily reflect their responses to the compounds individually. Interactions between stimulanting molecules may occur before the cell is stimulated, and there are also neuronal interactions after the electrical events start (Chapman 2003). The Central Nervous System processes multimodal sensorial stimuli, thus impulses combinations are naturally occurring (Rice 1989). In Groups 1 and 2 , in the concentration used and in combination to brewer's yeast, glucose and sucrose may have stimulated similarly the chemoreceptor to with they bond, resulting in similar behavioral responses.

In spite of females fed on yeast and sucrose (Group 4) selected substrates with sucrose on 2 days, females fed on yeast and glucose also did it. This result may be due to the higher stimulation power of sucrose on the sensorial receptors and not to the adult food influence. Thus, the effect of adult food on the selection of oviposition host was not found in the groups whose substrates did not contain brewer's yeast (Groups 3 and 4).

Table I. Number of eggs laid on each of the 6-day selection period on YG (yeast and glucose) and YS (yeast and sucrose) substrates, by $A$. obliqua flies fed on yeast and glucose (Group 1) or yeast and sucrose (Group 2) diets.

\begin{tabular}{ccccc}
\hline \multirow{2}{*}{ Group } & $\begin{array}{c}\text { Day of } \\
\text { selection }\end{array}$ & \multicolumn{2}{c}{ Number of eggs/substrate } & p value \\
& YG & YS & \\
\hline \multirow{4}{*}{1} & $1^{\text {st }}$ day & $67.4 \pm 29.49$ & $69.9 \pm 45.50$ & $\mathrm{p}=0.922$ \\
& $2^{\text {nd }}$ day & $52.1 \pm 17.40$ & $61.8 \pm 35.95$ & $\mathrm{p}=0.322$ \\
& $3^{\text {rd }}$ day & $80.8 \pm 44.21$ & $70.1 \pm 35.77$ & $\mathrm{p}=0.922$ \\
& $4^{\text {th }}$ day & $68.6 \pm 41.34$ & $74.5 \pm 47.05$ & $\mathrm{p}=0.734$ \\
& $5^{\text {th }}$ day & $66.8 \pm 29.94$ & $81.8 \pm 60.63$ & $\mathrm{p}=0.695$ \\
& $6^{\text {th }}$ day & $94.3 \pm 33.36$ & $50.4 \pm 15.59$ & $\mathrm{p}=0.004 *$ \\
& $1^{\text {st }}$ day & $30.2 \pm 23.22$ & $44.3 \pm 32.52$ & $\mathrm{p}=0.084$ \\
2 & $2^{\text {nd }}$ day & $40.0 \pm 26.84$ & $34.0 \pm 20.94$ & $\mathrm{p}=0.275$ \\
& $3^{\text {rd }}$ day & $58.8 \pm 28.98$ & $43.6 \pm 16.81$ & $\mathrm{p}=0.232$ \\
& $4^{\text {th }}$ day & $42.9 \pm 24.00$ & $44.7 \pm 22.14$ & $\mathrm{p}=1.000$ \\
& $5^{\text {th }}$ day & $55.7 \pm 29.94$ & $59.4 \pm 33.07$ & $\mathrm{p}=0.770$ \\
& $6^{\text {th }}$ day & $40.1 \pm 14.46$ & $41.6 \pm 19.52$ & $\mathrm{p}=0.992$ \\
\hline
\end{tabular}

The results represent the mean \pm standard deviation of 10 experimental boxes. * indicates significant difference, according to the Wilcoxon test, $\mathrm{p}<0.05$. 
Both carbohydrates tested are greatly available in nature and present an adequate nutritional value to fruit flies (Zucoloto 1992, 1993). During the reproductive life, A. obliqua flies, which are polyphagous, experience several kinds of food and oviposition sources. Therefore, throughout the evolutive history of the group, it seems that there was no environmental pressure to select acquisition or maintenance of mechanisms to allow the existence of adult food influence on selection of host oviposition, concerning carbohydrates as glucose and sucrose.

The sensitivity of the deterrent or phagostimulatory receptors changes with age, nutritional status and experience (Bernays 1995; Chapman 2003). Thus, we believe that a similar change may happen to chemoreceptors involved in the oviposition behavior.

According to Bernays (1995), the advantage of the effect of experience to insects, in a whole, is the simplification of the pathways that lead information to the Central Nervous System, contributing to a more efficient search for food and/or oviposition host, and also to a smaller exposition to dangerous situations (e.g., predation).

As the flies fed on yeast and sucrose (Group 2) showed no oviposition preference between the YG and YS substrates, the existence of behavioral induction for the oviposition substrate selection would be verified if flies from the Groups 5 and 6 showed preference by the substrate with similar composition to which they had a previous contact. Thus, the preference for the YS substrate, on 2 days, by the females which had a previous contact to it (Group 6) may be explained as an effect of experience.

Both sugars studied have similar nutritional value for $A$. obliqua (Fontellas \& Zucoloto, 1999) but in plants, there is a higher occurrence of sucrose in relation to glucose (Bernays $\&$ Chapman 2000). Thus, there may have been a higher pressure of selection in favor of the existence of effect of experience on selection of host oviposition due to the previous contact with the most abundant carbohydrate. This may explain the effect of experience found when the previous contact was done with YS substrates (Group 6), what was not found when the females had a previous contact with YG substrates (Group 5).

In relation to Group 6, we also observed that, on the first day, there was no preference for the YS substrate. Bernays (1995) calls "stimulant effect of novelty" the rejection, by an insect, of a certain food eaten during a period, when the insect has a new food available. In the present work, we consider the occurrence of the stimulant effect of novelty (provided by the YG) and the effect of experience (provided by the previous contact to the YS) on the oviposition behavior. As the experiments were performed with 10 wild females in each experimental box, there are great variability and plasticity in relation to the behavioral responses involved. During 3 days the flies oviposited in YS; on the fourth day, there was another substrate available (YG). The presence of YG (novelty) may have been stimulant to some females, as the effect of experience of YS may have been to others. As a result of the two stimulant effects, there was no difference in the number of eggs laid in
Table II. Number of eggs laid on each of the 6-day selection period on $\mathrm{G}$ (glucose) and $\mathrm{S}$ (sucrose) substrates, by A. obliqua flies fed on yeast and glucose (Group 3) or yeast and sucrose (Group 4) diets.

\begin{tabular}{ccccc}
\hline \multirow{2}{*}{ Group } & $\begin{array}{c}\text { Day of } \\
\text { selection }\end{array}$ & \multicolumn{2}{c}{ Number of eggs/substrate } & p value \\
& $1^{\text {st }}$ day & $22.8 \pm 17.43$ & $39.2 \pm 35.25$ & $\mathrm{p}=0.193$ \\
\multirow{4}{*}{3} & $2^{\text {nd }}$ day & $19.2 \pm 10.82$ & $31.8 \pm 17.40$ & $\mathrm{p}=0.008^{*}$ \\
& $3^{\text {rd }}$ day & $31.1 \pm 23.81$ & $50.5 \pm 28.60$ & $\mathrm{p}=0.025^{*}$ \\
& $4^{\text {th }}$ day & $35.1 \pm 23.59$ & $47.9 \pm 29.65$ & $\mathrm{p}=0.332$ \\
& $5^{\text {th }}$ day & $32.5 \pm 27.06$ & $48.5 \pm 20.34$ & $\mathrm{p}=0.064$ \\
& $6^{\text {th }}$ day & $34.7 \pm 21.51$ & $44.3 \pm 27.77$ & $\mathrm{p}=0.131$ \\
& $1^{\text {st }}$ day & $43.4 \pm 15.42$ & $79.0 \pm 37.86$ & $\mathrm{p}=0.014^{*}$ \\
4 & $2^{\text {nd }}$ day & $48.9 \pm 35.64$ & $71.8 \pm 51.66$ & $\mathrm{p}=0.275$ \\
& $3^{\text {rd }}$ day & $64.3 \pm 25.07$ & $73.3 \pm 30.60$ & $\mathrm{p}=0.375$ \\
& $4^{\text {th }}$ day & $58.1 \pm 25.89$ & $76.8 \pm 27.58$ & $\mathrm{p}=0.084$ \\
& $5^{\text {th }}$ day & $65.4 \pm 19.10$ & $75.1 \pm 31.86$ & $\mathrm{p}=0.625$ \\
& $6^{\text {th }}$ day & $43.5 \pm 20.36$ & $71.4 \pm 23.30$ & $\mathrm{p}=0.002^{*}$ \\
\hline
\end{tabular}

$\overline{\text { The results represent the mean } \pm \text { standard deviation of } 10 \text { experimental }}$ boxes. * indicates significant difference, according to the Wilcoxon test, $\mathrm{p}<0.05$.

both substrates on the first day. We believe that on the following days the effect of experience prevailed.

According to Sugayama \& Malavasi (2000), a wide range of behaviors shown by a species gives it a higher probability of adapting to a new condition. Thus, a polyphagous insect with high behavioral adaptability, as A. obliqua, may keep a large number of hosts. Several authors (Carey et al. 1986; Prokopy \& Reynolds 1998; Díaz-Fleischer \& Aluja 2003a, $2003 \mathrm{~b}$ ) and the present study have reported the plasticity of fruit flies concerning their oviposition behavior strategies. In this sense, further investigations on the factors related to this behavior are needed.

Acknowledgments. The authors are grateful to Ana Paula dos Santos and Laércio Massocato for the confection of diets and pupae collects, and to PhD Carla Cresoni-Pereira for the critical reading of the manuscript. T.A.B.S. Leal had a master scholarship from FAPESP (Proc. No. 02/11613-9).

\section{REFERENCES}

Aluja, M.; Piñero, J.; Jácome, I.; Díaz-Fleischer, F. \& J. Sivinski. 2000. Behavior of flies in the genus Anastrepha (Trypetinae: Toxotrypanini), p. 375-410. In: Aluja, M. \& Norrbom, A. L. (ed.). Fruit flies (Tephritidae): Phylogeny and Evolution of Behavior. NY: CRC Press.

Bernays, E. A. 1995. Effect of experience on feeding, p. 279-306. In: Chapman, R. F. \& Boer, G. (ed.) Regulatory Mechanisms in Insect Feeding. NY: Chapman \& Hale, 398 p.

Bernays, E. A. \& R. F. Chapman. 2000. Plant secondary compounds and grasshoppers: beyond plant defenses. Journal of Chemical Ecology 26: 1773-1793.

Bernays, E. A. \& M. R. Weiss. 1996. Induced food preferences in caterpillars: the need to identify mechanisms. Entomologia Experimentalis et Applicata 78: 1-8.

Canato, C. M. \& F. S. Zucoloto. 1998. Feeding behavior of Ceratitis capitata (Diptera, Tephritidae): Influence of carbohydrate ingestion. Journal of Insect Physiology 44: 149-155. 
Carey, J. R.; D. A. Krainaker \& R. I. Vargas. 1986. Life history of females Mediterranean fruit flies, Ceratitis capitata, to periods of host deprivation. Entomologia Experimentalis et Applicata 42: $159-167$.

Chapman, R. F. 2003. Contact chemoreception in feeding by phytophagous insects. Annual Review of Entomology 48: 455484.

Crnjar, R. M. \& R. J. Prokopy. 1982. Morphological and electrophysiological mapping of tarsal chemoreceptors of oviposition-deterring pheromone in Rhagoletis pomonella flies. Journal of Insect Physiology 28: 393-400.

Cunningham, J. P.; M. F. A. Jallow; D. J. Wright \& M. P. Zalucki. 1998. Learning in host selection in Helicoverpa armigera (Hübner) (Lepidoptera: Noctuidae). Animal Behaviour 55: 227-234.

Dethier, V. G. 1982. Mechanism of host-plant recognition. Entomologia Experimentalis et Applicata 31: 49-56.

Díaz-Fleischer, F. \& M. Aluja. 2003a. Behavioural plasticity in relation to egg and time limitation: the case of two fly species in the genus Anastrepha (Diptera: Tephritidae). Oikos 100: 125-133.

Díaz-Fleischer, F. \& M. Aluja. 2003b. Clutch size in frugivorous insects as a function of host firmness: the case of tephritid fly Anastrepha ludens. Ecological Entomology 28: 268-277.

Dukas, R.; R. J. Prokopy; D. R. Papaj \& J. J. Duan. 2001. Egg laying behavior of mediterranean fruit flies (Diptera: Tephritidae): is social facilitation important? Florida Entomologist 84: 665-671.

Fontellas, T. M. L. \& F. S. Zucoloto. 1999. Nutritive value of diets with different carbohydrates for adult Anastrepha obliqua (Macquart) (Diptera: Tephritidae). Revista Brasileira de Zoologia 16: 1135-1147.

Fontellas-Brandalha, T. M. L. \& F. S. Zucoloto. 2004. Selection of oviposition sites by wild Anastrepha obliqua (Macquart) (Diptera: Tephritidae) based on the nutritional composition. Neotropical Entomology 33: $557-562$.

Gothilf, S.; R. Galun \& M. Bar-Zeev. 1971. Taste reception in the Mediterranean fruit fly: electrophysiological and behavioural studies. Journal of Insect Physiology 17: 1371-1384.

Joaquim-Bravo, I. S.; O. A. Fernandes; S. A. Bortoli \& F. S. Zucoloto. 2001. Oviposition preference hierarchy in Ceratitis capitata (Diptera: Tephritidae): Influence of female age and experience. Iheringia, Série Zoologia 91: 93-100.

Miyakawa, Y. 1982. Behavioral evidence for the existence of sugar, salt and amino acid taste receptor cells and some of their properties in Drosophila larvae. Journal of Insect Physiology 28: 405410 .

Nufio, C. R. \& D. R. Papaj. 2004. Superparasitism of larval hosts by the walnut fly, Rhagoletis juglandis, and its implications for female and offspring performance. Oecologia 141: 460-467.

Papaj, D. R. \& R. J. Prokopy. 1989. Ecological and evolutionary aspects of learning in phytophagous insects. Annual Review of Entomology 34: 315-350

Prokopy, R. J. \& A. H. Reynolds. 1998. Ovipositional enhancement through social facilitated behavior in Rhagoletis pomonella flies. Entomologia Experimentalis et Applicata 86: 281-286.

Prokopy, R. J. \& B. D. Roitberg. 1984. Foraging behavior of true fruit flies. American Scientist 72: 41-49.

Rice, M. J. 1989. The Sensory Physiology of Pest Fruit Flies: Conspectus and Prospectus, p. 249-272. In: Robinson, A. S. \& Hooper, G. (ed.). Fruit Flies Their Biology, Natural Enemies and Control - vol. 3A. Amsterdam: Elsevier, 372 p.

Scheirs, J. 2002. Integrating optimal foraging and optimal oviposition theory in plant-insect research. Oikos 96: 187-191.

Scheirs, J.; L. De Bruyn \& R. Verhagen. 2000. Optimization of adult performance determines host choice in a grass miner. Proceedings of the Royal Society of London. Series B. Biological Sciences 267: 2065-2069.

Sugayama, R. L. \& A. Malavasi. 2000. Ecologia Comportamental, p. 103-108. In: Malavasi, A. \& R. A. Zucchi. (ed.). Moscas-dasfrutas de Importância Econômica no Brasil - Conhecimento Básico e Aplicado. Ribeirão Preto, Holos, 327 p.

Thompson, J. N. 1988. Evolution ecology of the relationship between oviposition preference and performance of offspring in phytophagous insects. Entomologia Experimentalis et Applicata 47: 3-14.

Thompson, J. N. \& O. Pellmyr. 1991. Evolution of oviposition behavior and host preference in Lepidoptera. Annual Review of Entomology 36: 65-89.

Zucoloto, F. S. 1992. Egg production by Ceratitis capitata (Diptera, Tephritidae) fed with different carboydrates. Revista Brasileira de Entomologia 36: 235-240.

Zucoloto, F. S. 1993. Nutritive value and selection of diets containing different carboydrates by larvae of Ceratitis capitata (Diptera, Tephritidae). Revista Brasileira de Biologia 53: 611-618. 